\title{
Trace element variations as a proxy for reconstruction of palaeoenvironmental changes during the Late Aeronian faunal and carbon isotope perturbations: new data from the peri-Gondwanan region
}

\author{
Jan PAŠAVA ${ }^{1, *}$, Jiří FRÝDA ${ }^{1,2}$ and Petr ŠTORCH ${ }^{3}$ \\ 1 Czech Geological Survey, Klárov 3/131, 11821 Prague 1, Czech Republic \\ 2 Czech University of Life Sciences Prague, Faculty of Environmental Sciences, Kamýcká 129, Praha 6 - Suchdol, \\ 165 21, Czech Republic \\ 3 Academy of Sciences of the Czech Republic, Institute of Geology, Rozvojová 135, Praha 6, 165 00, Czech Republic
}

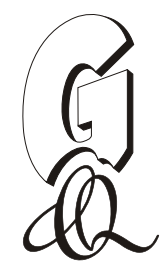

\begin{abstract}
Pašava, J., Frýda, J., Štorch, P., 2017. Trace element variations as a proxy for reconstruction of palaeoenvironmental changes during the Late Aeronian faunal and carbon isotope perturbations: new data from the peri-Gondwanan region. Geological Quarterly, 61 (1): 91-98, doi: 10.7306/gq.1313

Trace element variations in the Upper Aeronian (Llandovery, Lower Silurian), deep-water, black shale succession of the Barrandian area (Perunica) were studied across an interval associated with a graptolite mass extinction and global, positive carbon isotope anomaly. The main aim of the paper is to test whether distinct changes in graptolite diversity during Late Aeronian were linked with changes in deep sea water oxygenation. Using multiple geochemical proxies we documented high-frequency changes in oxygenation of sea water from sediments of the convolutus to linnaei (guerichi) biozones. Detailed comparison of graptolite diversity with those high-frequency oxygenation changes suggests that the long-term and step-wise Late Aeronian graptolite crisis was not significantly influenced by changes in oxygen level and thus it probably resulted by another causes. The collapse of global carbon cycle during the Late Aeronian probably only temporarily increased extinction rate of the long-term graptolite crisis and considerably decreased evenness of the uppermost Aeronian graptolite communities. The Aeronian graptolite mass extinction was thus primarily driven by other biotic and/or abiotic causes.
\end{abstract}

Key words: aeronian, graptolite mass extinction, redox-sensitive trace elements, Barrandian area, Bohemian Massif.

\section{INTRODUCTION}

Redox-sensitive trace element (RSTE) concentrations or ratios are often used as indicators of redox conditions in modern and ancient sedimentary systems (e.g., Hatch and Leventhal, 1992; Calvert and Pedersen, 1993; Jones and Manning, 1994; Wignall, 1994; Morford and Emerson, 1999; Yarincik et al., 2000; Tribovillard et al., 2006). RSTE usually show significant enrichment in finely laminated, organic-rich facies that originated mostly under anoxic/euxinic conditions, whereas bioturbated, organic-poor facies usually show no metal enrichment (e.g., Pašava et al., 1996; Pašava, 2000; Algeo and Maynard, 2004; Tribovillard et al., 2006). Hammarlund et al. (2012) used geochemical redox indicators, such as iron speciation, molybdenum concentrations, pyrite framboid size distribution and sulphur isotopes for the end-Ordovician extinction. They concluded that the expansion of euxinic condi-

\section{* Corresponding author, e-mail: jan.pasava@geology.cz}

Received: April 29, 2016; accepted: July 20, 2016; first published online: September 14, 2016 tions during the extraordinarius Biozone was generated by a reorganization of nutrient cycling during sea level fall, and argued, that these dynamics in ocean chemistry played an important role for the end-Ordovician mass extinction. Most recently, however, new drivers for the extinctions have been proposed, including widespread euxinia together with habitat destruction caused by plate tectonic movements, suggesting that the end-Ordovician mass extinctions were a product of the coincidence of a number of contributing factors (Harper et al., 2014). Vandenbroucke et al. (2015) showed that metal poisoning may have caused aberrant morphologies during a Late Silurian (Pridoli) event. Malformations coincide with a dramatic increase of metals (Fe, Mo, $\mathrm{Pb}, \mathrm{Mn}$ and $\mathrm{As}$ ) in the fossils and their host rocks. Porebska and Sawłowicz (1997) found that Si/Al, $\mathrm{Si} / \mathrm{Al} / \mathrm{TOC}, \mathrm{Ga} / \mathrm{Al}_{2} \mathrm{O}_{3}, \mathrm{~V} / \mathrm{V}+\mathrm{Ni}$ ratios and TOC, Mn, Ti, Re, Mo, $\mathrm{Cd}, \mathrm{Cu}$ and REE correlate with the habitat replacement of the graptolite assemblages in black shales across the Silurian-Devonian boundary. Bond et al. (2013) related marine extinctions in offshore level bottom communities of Frasnian-Famenian reefs (Alberta, Canada) to two widespread, transgressive, anoxic "Kellwasser Events" that support an anoxia-extinction link.

The Lower Silurian black-shales of the Prague Synform (Perunica; see Cocks and Torsvik, 2013) offer favourable conditions for studying the geochemical signatures of redox facies in organic-rich sedimentary rocks. Štorch and Frýda (2012) re- 
cently studied a set of samples from Aeronian and lowermost Telychian black shale succession temporarily exposed in the highway tunnel north of Radotín near Prague (Fig. 1). They focused primarily on the precise biostratigraphic timing and interpretation of the Late Aeronian graptolite mass extinction (referred to as the sedgwickii Event) and the associated positive carbon isotope excursion and facies changes. Unique, fresh material from the Radotín tunnel section and its high-resolution graptolite biostratigraphy provided a good opportunity for detailed geochemical investigations of large, high-frequency changes in Aeronian sea water chemistry. The main aim of the present paper is to test the hypothesis that distinct changes in graptolite faunal dynamics during the Middle-Late Aeronian, culminating in the Late Aeronian graptolite mass extinction, are linked with changes in Aeronian deep sea water oxygenation.

\section{GEOLOGICAL, LITHOLOGICAL AND BIOSTRATIGRAPHICAL DESCRIPTION}

Anoxic depositional settings in the Prague Basin commenced at the base of the Silurian System in response to the Late Hirnantian-Rhuddanian anoxic event (e.g., Melchin et al., 2013) and produced organic rich shales with TOC over 2-3 wt.\%, which were deposited until the Early Ludlow in much of the preserved outcrop area of the Prague Synform (see for details Krížz, 1998). The combined thickness of the predominantly black shale succession of the Želkovice (Rhuddanian-Aeronian), Litohlavy (Lower and Middle Telychian) and Motol (Upper Telychian-Homerian) formations varies from $125 \mathrm{~m}$ (purely black shale succession) to $350 \mathrm{~m}$ (in volcanic-carbonate facies; Kř́ž, 1998). Depositional settings, biotic and environmental changes, and stratigraphy have been studied in the Lower Silurian succession of the Prague Synform by Bouček (1953), Kř́žž (1975, 1992), Štorch and Pašava (1989), Štorch (2006), Štorch and Frýda (2012), Frýda and Štorch (2014) and others. High-resolution correlation of lithological changes recorded in the Lower Silurian succession with environmentally driven, world-wide changes is enabled by highly developed graptolite biostratigraphy (Bouček, 1953; Štorch, 1994, 2006) and carbon isotope geochemistry (Frýda and Frýdová, 2014 2016; Frýda and Štorch, 2014; Frýda et al., 2014). The geochemistry of Lower Silurian sequences in the Prague Synform was first studied by Marešová (1973), followed by Lepka et al. (1984). Later, Štorch and Pašava (1989) recorded significant enrichment in Mo and to a lesser degree in $\mathrm{Cu}, \mathrm{Ni}, \mathrm{Cr}$ and $\mathrm{S}$ in the Lower Silurian black shales of the Prague Synform and suggested that the distributions of $\mathrm{Mo}, \mathrm{Cu}$, $\mathrm{Ni}$ and $\mathrm{Pb}$ are closely related to TOC.

The general geology of the Želkovice (Rhuddanian-Aeronian) Formation, its graptolite biostratigraphy and carbon isotope chemostratigraphy, as well as detailed description of the Radotín tunnel section (Figs. 1 and 2), were provided by Štorch and Frýda (2012) and Frýda and Štorch (2014). The first significant change in the sedimentary succession was found near the top of convolutus Biozone in the Radotín tunnel section. It is associated with a gradual but considerable impoverishment of high-diversity graptolite assemblage. Siliceous black shales of the convolutus Biozone pass up into pyrite-rich, graptolite-poor shale with low TOC (ca. 3 wt.\%). Uncommon graptolites refer this shale to the lower part of sedgwickii Biozone. It is overlain by a heavily bioturbated, micaceous siltstone without identifiable graptolites (the marker bed which is characterized by positive $\delta^{13} \mathrm{C}$ anomaly), which, in turn, is succeeded by organic rich (TOC ca. 6 wt.\%), finely laminated, micaceous black shales with an abundant, but still lower diversity, graptolite fauna (Fig. 2). Faunal differences between the graptolite assemblage below and above the siltstone (Fig. 2) and the abrupt change in grain size and TOC suggest that an interval of non-deposition and/or erosion may be associated with the deposition of the siltstone bed. The organic-rich, micaceous black shales above the siltstone bed are assigned to the upper part of the sedgwickii Biozone (see Fig. 2). The stratigraphical ranges of numerous graptolite species span the interval. Hence the potential stratigraphical break likely represents a short duration, still within the middle part of the sedgwickii Biozone. Organic-rich, micaceous shales of the upper sedgwickii Biozone are overlain by black, clayey shales with abundant graptolites of rastrum Biozone

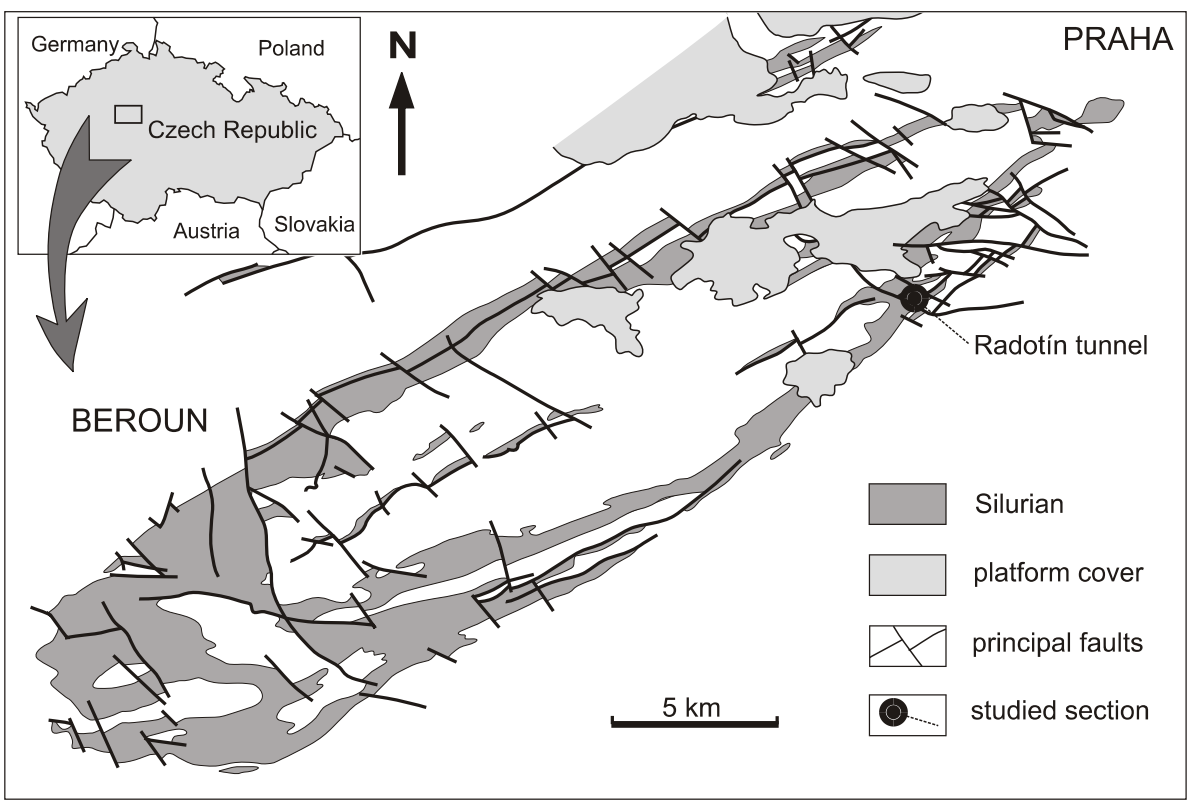

Fig. 1. Distribution of Silurian rocks in the Barrandian area, including the locations of the studied section 

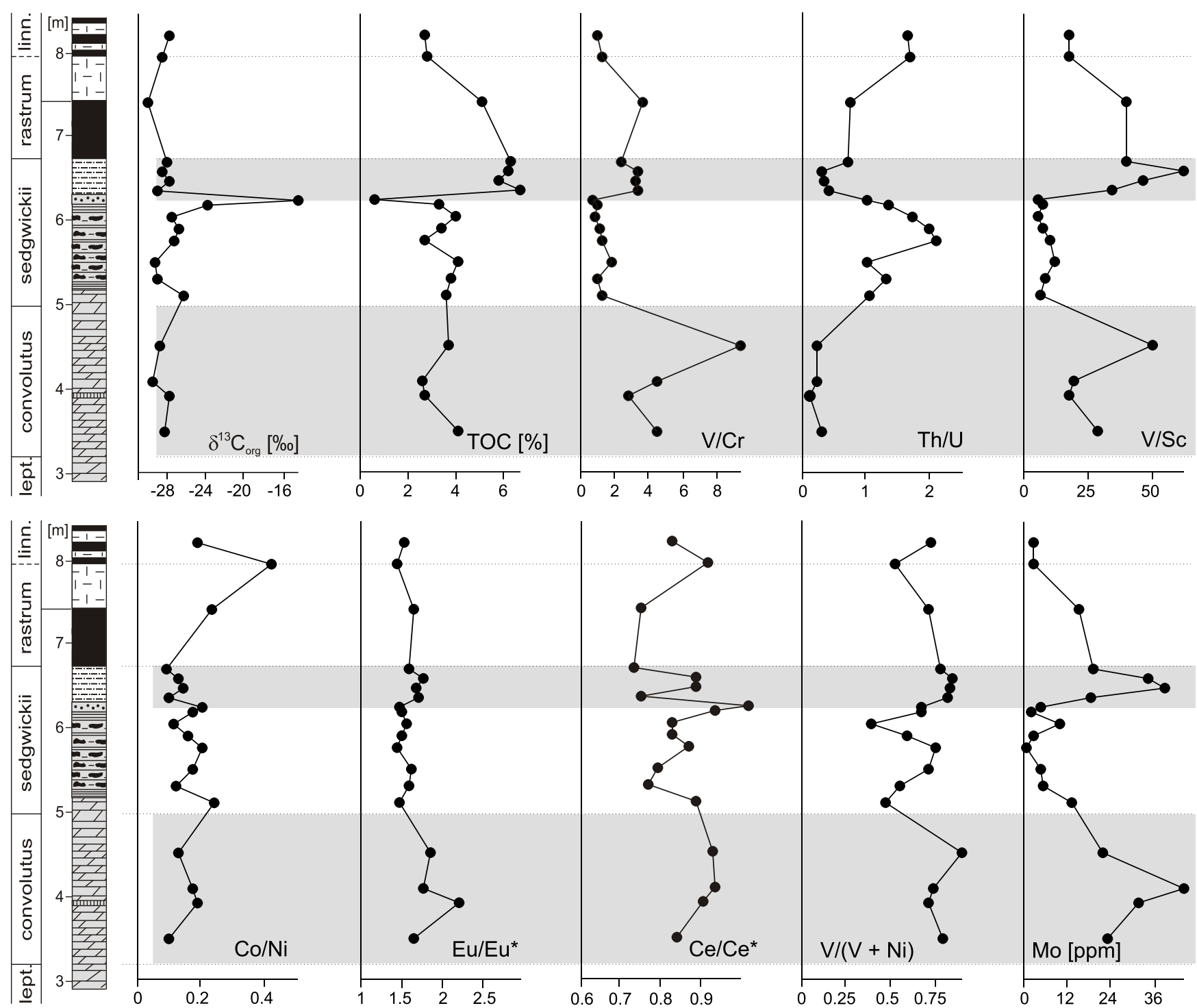

fine black shale
$\because \therefore \because$ mottled micaceous siltstone

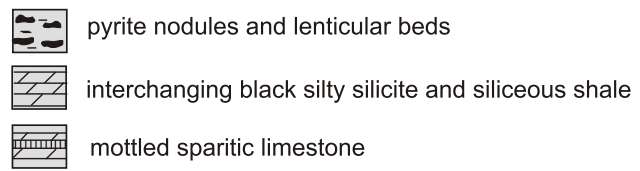

Fig. 2. Stratigraphical distribution of $\delta^{13} \mathrm{C}$ and TOC composition and values of selected ratios of redox-sensitive trace elements

For detailed description of lithology see Štorch and Frýda (2012);

grey areas represent intervals interpreted to represent low oxygen level in bottom sea water

immediately below a thick bed of pale-coloured mudstone (Fig. 2). The massive bed of pale-coloured, mottled carbonate mudstone, without graptolites, forms the base of the Litohlavy Fm. Lowermost Telychian graptolites of linnaei Biozone (approximate equivalent of guerichi Biozone) appear in the black claystone intercalations just above the basal mudstone. The highly diversified Aeronian graptolite fauna collected from the Radotín tunnel section enabled a detailed analysis of the evolution of graptolite diversity. Štorch and Frýda (2012) noted a close link between graptolite faunal dynamics and carbon isotope anomaly in the Late Aeronian interval.

\section{METHODS}

In this paper we studied 19 samples from predominantly black shale sedimentary succession exposed in the highway tunnel (Fig. 1) north of Radotín, near Prague, which was previously documented by Štorch and Frýda (2012). The unweathered Llandovery black-shale succession, rich in well-preserved graptolites, yielded excellent samples for TOC and carbon isotope analyses (Štorch and Frýda, 2012; Frýda and Štorch, 2014) as well as for analyses of other elements, including redox sensi- 
tive trace elements (RSTE) and rare earth elements (REE). As a result, this subsurface section is of particular significance.

The samples were powdered and analysed for selected major and trace elements in labs of the Czech Geological Survey. $\mathrm{REE}, \mathrm{Cr}$, Co, Fe, Ti, Mo, Ni, Sc, Th, U, V and Zr were determined using ICP-X Series. Total sulphur was measured using the spectrometric IR (Eltra) method. The TOC and $\delta^{13} \mathrm{C}$ data are from Štorch and Frýda (2012), and Frýda and Štorch (2014).

Cerium $\left(\mathrm{Ce} / \mathrm{Ce}^{*}\right)$ and europium $\left(\mathrm{Eu} / \mathrm{Eu}^{*}\right)$ anomalies were calculated from: $\mathrm{Ce} / \mathrm{Ce}^{*}=\mathrm{Ce}_{n} /\left(\mathrm{La}_{\mathrm{n}} \times \mathrm{Pr}_{\mathrm{n}}\right)^{1 / 2}$ and $\mathrm{Eu} / \mathrm{Eu}^{*}=$ $\mathrm{Eu}_{n} /\left(\mathrm{Sm}_{\mathrm{n}} \times \mathrm{Gd}_{n}\right)^{1 / 2}$ (Taylor and McLennan, 1985), using shale-normalized abundances. Normalization values are a mean of North American, European and Russian shale composites.

In this paper, we report whole-rock trace element concentrations (Appendix $1^{*}$ ) and estimate the proportion of each trace element resident in the detrital fraction of black shale samples using normalization by $\mathrm{Zr}$ and Ti which are chiefly of detrital origin (e.g., Calvert and Pedersen, 1993; Wignall, 1994; Algeo and Maynard, 2004 and others). We show that plotted concen- trations and values of metal ratios of redox-sensitive trace elements dominantly reflect their authigenic values and discuss some exceptions related to their detrital contribution in the following chapters.

\section{RESULTS}

The stratigraphic distribution of most ratios of selected trace elements is shown in Figures 2 and 3.

Convolutus Biozone. The $\delta^{13} \mathrm{C}_{\text {org }}$ and TOC values of four samples from the convolutus Biozone are relatively constant. On the other hand, concentrations of $\mathrm{Mo}$ and $\mathrm{V}$, as well as $\mathrm{V} / \mathrm{Cr}$, $\mathrm{V} / \mathrm{Sc}, \mathrm{Ce} / \mathrm{Ce}^{*}$ and $\mathrm{Eu} / \mathrm{Eu}^{*}$ ratios are variable. The values of $\mathrm{V} / \mathrm{Cr}, \mathrm{V} / \mathrm{Sc}, \mathrm{V} /(\mathrm{V}+\mathrm{Ni}), \mathrm{Ce} / \mathrm{Ce}^{*}$ and $\mathrm{Eu} / \mathrm{Eu}^{*}$ ratios are high and some of those [i.e., $\mathrm{V} / \mathrm{Cr}(9.3), \mathrm{V} /(\mathrm{V}+\mathrm{Ni})(0.9)$ and $\left.\mathrm{Eu} / \mathrm{Eu}^{*}(2.2)\right]$ reach their highest values in the studied section (Fig. 2). In contrast, the $\mathrm{Th} / \mathrm{U}$ ratios and $\mathrm{Fe}$ and $\mathrm{S}$ concentrations reach their lowest values (Figs. 2 and 3).
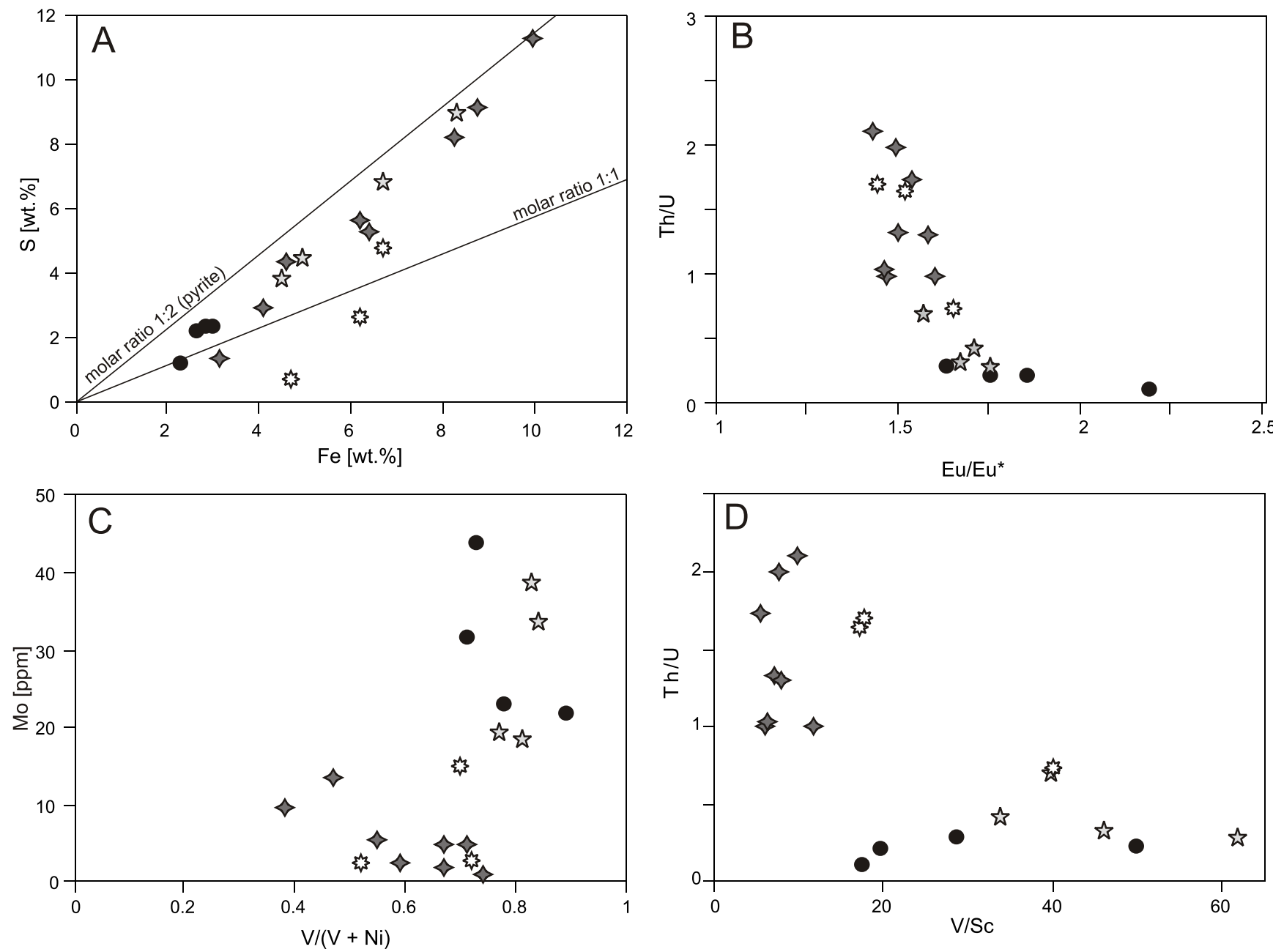

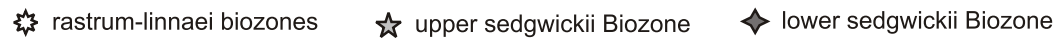

convolutus Biozone

Fig. 3. Plots illustrating relationship of $\mathrm{Fe}$ and $\mathrm{S}$ contents $(\mathrm{A}), \mathrm{Eu} / \mathrm{Eu}^{*}$ and $\mathrm{Th} / \mathrm{U}$ ratios $(\mathrm{B}) \mathrm{V} /(\mathrm{V}+\mathrm{Ni})$ ratio and Mo content (C), and V/Sc and Th/U ratios (D) 
Sedgwickii Biozone. Relatively low $\mathrm{V} / \mathrm{Cr}, \mathrm{V} / \mathrm{Sc}, \mathrm{V} /(\mathrm{V}+\mathrm{Ni})$, $\mathrm{Ce} / \mathrm{Ce}^{*}$ and $\mathrm{Eu} / \mathrm{Eu}^{*}$ ratios and $\mathrm{Mo}$ and $\mathrm{V}$ concentrations and increased $\mathrm{Th} / \mathrm{U}$ ratios and $\mathrm{Fe}$ and $\mathrm{S}$ concentrations are characteristic features of the eight samples from the lower part of the sedgwickii Biozone. The Th/U ratio reaches its maximum value (2.1) and the Mo concentration its minimum value $(0.8 \mathrm{ppm})$ in the same level, about $0.5 \mathrm{~m}$ below the peak of the Late Aeronian positive carbon isotope anomaly (Fig. 2), which corresponds to the top of the lower part of the sedgwickii Biozone. The carbon isotope anomaly is associated with very low TOC and $\mathrm{Ni}$ concentrations (Appendix 1).

Analyses of four samples from the upper part of the sedgwickii Biozone revealed a rapid increase in the $\mathrm{V} / \mathrm{Cr}$, V/Sc, $\mathrm{V} /(\mathrm{V}+\mathrm{Ni})$, and $\mathrm{Ce} / \mathrm{Ce}^{*}$ ratios and $\mathrm{Mo}, \mathrm{Ni}, \mathrm{V}$ and $\mathrm{TOC}$ concentrations (Appendix 1). The V/Sc ratio (61.7), as well as TOC (6.6 wt.\%), Mo (39 ppm), and V (1289 ppm) concentrations, reach their maximum values in this interval within the studied section. A notable decrease of $\mathrm{Th} / \mathrm{U}$ ratios within the upper part of the sedgwickii Biozone represents a culmination of a distinct trend, which started below the Upper Aeronian carbon isotope anomaly (Fig. 2).

Rastrum and linnaei biozones. Upward decreases in the values of the V/Sc ratios and TOC, Mo, and V concentrations (Appendix 1), as well as an increasing trend in the $\mathrm{Th} / \mathrm{U}$ ratio, characterize the three samples from the rastrum and linnaei biozones.

\section{ENVIRONMENTAL CHANGES INFERRED FROM GEOCHEMICAL PROXIES}

In the following section changes in the oxygen level in the Aeronian marine environment are estimated based on several geochemical proxies, which are discussed separately.

\section{VANADIUM [V/Sc, V/Cr, V/(V + Ni)] SYSTEMATICS}

Vanadium is a redox-sensitive element that is preferentially concentrated in marine sediments underlying anoxic or near-anoxic waters (e.g., Emerson and Huested, 1991; Rimmer, 2004). The degree of $V$ enrichment is most efficiently expressed if the $V$ concentration is normalized by scandium abundance, because both $\mathrm{V}$ and $\mathrm{Sc}$ are insoluble and $\mathrm{V}$ varies in proportion to Sc, rather than to other insoluble elements such as $\mathrm{Al}$ and $\mathrm{Ti}$ (Kimura and Watanabe, 2001). Kimura and Watanabe (2001) suggested that environments characterized by anoxic conditions resulted in significant $\mathrm{V}$ enrichment over Sc. In addition, Jones and Manning (1994) proposed that V/Cr ratios $<2$ pointed to oxic conditions, $2-4.25$ to dysoxic conditions, and $>4.25$ to suboxic to anoxic conditions. Similarly, Hatch and Leventhal (1992) reported $\mathrm{V} /(\mathrm{V}+\mathrm{Ni})$ ratios $0.46-0.60$ for dysoxic conditions, $0.54-0.82$ for anoxic conditions, and $>0.84$ for euxinic conditions. Normalization of $\mathrm{V}$ and $\mathrm{Ni}$ values by $\mathrm{Zr}$ showed that $\mathrm{Ni}$ is authigenic while $\mathrm{V}$ showed a slight detritic input in the upper part of the sedgwickii Biozone and also in rastrum and linnaei Biozone. In this context, the four samples from the convolutus Biozone with high values of the V/Sc ratio (17.3-49.7; avg. 28.8), $\mathrm{V} / \mathrm{Cr}$ ratio (2.8-9.3, avg. 5.2) and $\mathrm{V} /(\mathrm{V}+$ $\mathrm{Ni}$ ratio (0.7-0.9; avg. 0.8; Fig. 3) clearly indicate dysoxic to anoxic bottom-water conditions (Fig. 3). This conclusion fits also with the highest enrichment in Mo (21.5-43.9 ppm; avg. $30 \mathrm{ppm}$ ), but does not, however, coincide with the highest TOC values (2.65-4.09 wt.\%; avg. 3.25 wt.\%). A different situation can be observed in the sedgwickii Biozone. In the lower part all eight samples show much lower ratios of V/Sc (5.5-11.7; avg. 7.7), $\mathrm{V} / \mathrm{Cr}(0.7-1.8$; avg. 1.1), and $\mathrm{V} /(\mathrm{V}+\mathrm{Ni})(0.4-0.7$; avg. 0.6; Fig. 3) indicating oxic to dysoxic conditions (Fig. 4). A lack of significant correlation between redox sensitive elements and TOC was probably influenced by increasing terrigenous influx just before the end of the time interval of the lower part of the sedgwickii Biozone (Fig. 3). Four samples from the upper part of the sedgwickii Biozone show a return to much higher V/Sc ratios (33.7-61.7; avg. 45.3) and also higher values of $\mathrm{V} / \mathrm{Cr}$ (2.4-3.4; avg. 3.1) and V/V + Ni (0.77-0.84; avg. 0.81; Fig. 3). The latter high values, together with higher concentrations of Mo (19.2-38.6 ppm; avg. 27.5 ppm) and TOC (5.7-6.6 wt.\%; avg. 6.2 wt.\%), clearly indicate return to dysoxic/anoxic deep-water environment. Three samples from the rastrum-linnaei biozones revealed an upward decreasing trend in values of $\mathrm{V} / \mathrm{Sc}$ (from 40.0 to 17.2 ) and $\mathrm{V} / \mathrm{Cr}$ (from 3.6 to 1.0) ratios, and low values of $\mathrm{V} / \mathrm{V}+\mathrm{Ni}(0.5-0.7$; Fig. 2$)$, documenting a return to oxic conditions. This conclusion is supported by low Mo (2.5-2.8 ppm) and TOC values (2.68-2.80 wt.\%).

\section{Th/U RATIO}

The Th/U ratio has been used as a proxy for the redox condition of the depositional environment (e.g., Myers and Wignall, 1987; Wignall, 1994). Thorium is unaffected by redox conditions and remains insoluble as $\mathrm{Th}^{4+}$. Uranium, however, exists as insoluble $\mathrm{U}^{4+}$ under highly reducing conditions, which leads to $U$ enrichment in sediments, whereas it exists as soluble $U^{6+}$ under oxidizing conditions, leading to the $U$ loss from sediments (Kimura and Watanabe, 2001). Wignall and Twitchett (1996) suggested that environments characterized by anoxic conditions yielded $T h / U$ ratios of 0 to 2 in shales, and this criterion has been widely accepted in subsequent studies (e.g., Kimura and Watanabe, 2001; Guo et al., 2007).

The four studied samples from the convolutus Biozone have very low values of the Th/ $U$ ratios $(0.11-0.29$; avg. 0.21 , which is typical for anoxic environments. Nevertheless, normalization of $U$ values by $\mathrm{Zr}$ indicates a possible slight detritic input of $\mathrm{U}$ in the upper part of the convolutus Biozone similarly as $\mathrm{V}$. On the other hand, values of the $T h / U$ ratios are increasing from the base of the lower part of the sedgwickii Biozone to its middle where the Th/ $U$ ratio reaches the maximum value of 2.1 , suggesting more oxic conditions relative to older strata. Subsequently values of the $\mathrm{Th} / \mathrm{U}$ ratios gradually decrease (Fig. 2) from 2.1 to 0.4 at the base of the upper part of the sedgwickii Biozone. These values clearly indicate a transition back to anoxic conditions, similar to those in the convolutus Biozone (Figs. 2 and 3). Anoxic conditions remained steady during the time of the upper part of the sedgwickii Biozone. Above the top of the sedgwickii Biozone the Th/U values again show a considerable increase indicating a distinct change from strongly anoxic to oxic environments (Figs. 3 and 4 ).

\section{$\mathrm{Fe} / \mathrm{S}$ RATIO}

The Fe/S ratio can be used as an indicator for the amount of sulphide-bound $\mathrm{Fe}$ in sedimentary strata - a lower value of the $\mathrm{Fe} / \mathrm{S}$ ratio indicates that more of the $\mathrm{Fe}$ is sulphide-bound (e.g., März et al., 2009). The Fe/S ratio in the studied samples ranges between 0.9 and 6.2. The vast majority of samples are close to the "pyrite line" but Fe-enriched (Fig. 3), suggesting that pyrite is the main phase controlling the content of $\mathrm{Fe}$ and $\mathrm{S}$. The maximum value of the $\mathrm{Fe} / \mathrm{S}$ ratio was measured in black shale of the linnaei Biozone (Fig. 3) and coincides with the lowest S/TOC ra- 
tio (0.3), a low value of $\mathrm{V} / \mathrm{Cr}$ and high $\mathrm{Th} / \mathrm{U}(1.6)$ and also the highest Th value (Appendix 1). This could indicate a terrigenous/volcanogenic input including detrital Fe (oxyhydr)oxides or other Fe-bearing minerals in a more oxic environment.

\section{$\mathrm{Ce} / \mathrm{Ce}^{*} \mathrm{AND} \mathrm{Eu} / \mathrm{Eu}^{*} \mathrm{RATIOS}$}

Normal sea water shows a marked depletion of $\mathrm{Ce}$, owing to the predominance of oxidation to $\mathrm{Ce}^{4+}$ and accumulation in the sediments as $\mathrm{CeO}_{2}$. In contrast, at a local redox-cline such as that in the Black Sea, $\mathrm{Ce}$ is reduced to $\mathrm{Ce}^{3+}$ and the $\mathrm{Ce}$ anomaly is not present (Rasmussen et al., 1998). Wright et al. (1987) and Wignall (1994) suggested that the Ce anomaly can record the redox conditions of the overlying sea water column, and that this signature remains in spite of subsequent burial and later diagenesis. Eu/Eu* anomalies have been reported in many types of igneous and sedimentary rocks and Eu anomalies play a significant role in interpreting the physical and chemical conditions (e.g., Derry and Jacobsen, 1990; MacRae et al., 1992; Fedo et al., 1996; Rasmussen et al., 1998; Lee et al., 2004; Sugitani et al., 2006 and others). Normalization of $\mathrm{Ce}$ and Eu values by $\mathrm{Zr}$ showed that both elements could indicate a local detritic input Ce in the upper part of the sedgwickii Biozone including the Upper Aeronian carbon isotope anomaly and also in the rastrum and linnaei biozones while Eu only close to the Upper Aeronian carbon isotope anomaly. Dominant terrigenous source of REE is indicated by the values of $\mathrm{Y} / \mathrm{Ho}$ ratio which range from 28 to 38 (median value 31 ) as $\mathrm{Y} / \mathrm{Ho}$ ratio of about 28 is typical for common igneous rocks and clastic sediments (Bau, 1996).

The calculated $\mathrm{Ce} / \mathrm{Ce}^{*}$ values in the studied samples vary in a narrow range, from 0.73 to 1.02 . The maximum value of the $\mathrm{Ce} / \mathrm{Ce}^{*}$ ratio $(1.02)$ comes from the heavily bioturbated micaceous siltstone deposited during the Late Aeronian carbon isotope anomaly. The rest of the samples have average values of $\mathrm{Ce} / \mathrm{Ce}^{*}$ ratios $(0.85)$ which fits well with a range of black shales deposited under low oxygen conditions (e.g., Yan et al., 2009). On the other hand, the $\mathrm{Eu} / \mathrm{Eu}^{*}$ values of the Radotín tunnel samples are high ranging from 1.43 to 2.19 (avg. 1.62). The high values of the Eu/Eu* ratio (including the maximum value of 2.19) occur in the convolutus Biozone (Fig. 2) and in the upper part of the sedgwickii Biozone, suggesting an oxygen-deficient environment. A negative correlation between the $\mathrm{Eu} / \mathrm{Eu}^{*}$ and $\mathrm{Th} / \mathrm{U}$ values indicates a dependence of the magnitude of the negative $\mathrm{Eu}^{*}$ anomaly on the degree of anoxicity (Fig. 3).

Taken together, the different geochemical proxies that we have measured suggest almost a recurring scenario of the deep-water oxygen level changes during the studied time span, from the convolutus to linneai biozones (Fig. 4). Distinctly anoxic to dysoxic conditions prevailed during time of the convolutus Biozone. From the beginning of the sedgwickii Biozone time interval the oxygen level in deep sea water was considerably higher, changing to dysoxic/oxic conditions in the middle of the lower part of the sedgwickii Biozone [maximum value of the $\mathrm{Th} / \mathrm{U}$, minimum value of $\mathrm{V} /(\mathrm{V}+\mathrm{Ni})$ and $\mathrm{Mo}$, etc.]. A pronounced reduction in oxygen level occurred just above the Late Aeronian carbon isotope anomaly (Fig. 4). The geochemical proxies employed here suggest a rapid shift to a more dysoxic/anoxic environment, which was stable until the end of the sedgwickii Biozone. The period of the rastrum-linnaei biozones is characterized by a return to oxic conditions (Fig. 4).

\section{RELATIONSHIP OF GRAPTOLITE FAUNAL DYNAMICS AND ENVIRONMENTAL CHANGES}

Štorch and Frýda (2012) analysed graptolite faunal dynamics during the Middle-Late Aeronian, from the leptotheca to rastrum biozones, based on the data from the Radotín tunnel section as well as all other available data from the Barrandian area. The analyses of data from the Radotín tunnel section, using different diversity indices, revealed a statistically significant decreasing trend in graptolite species diversity from the leptotheca to lower sedgwickii biozones and a further, distinct decrease in graptolite species richness between the lower and upper parts of the sedgwickii Biozone (Fig. 4; Štorch

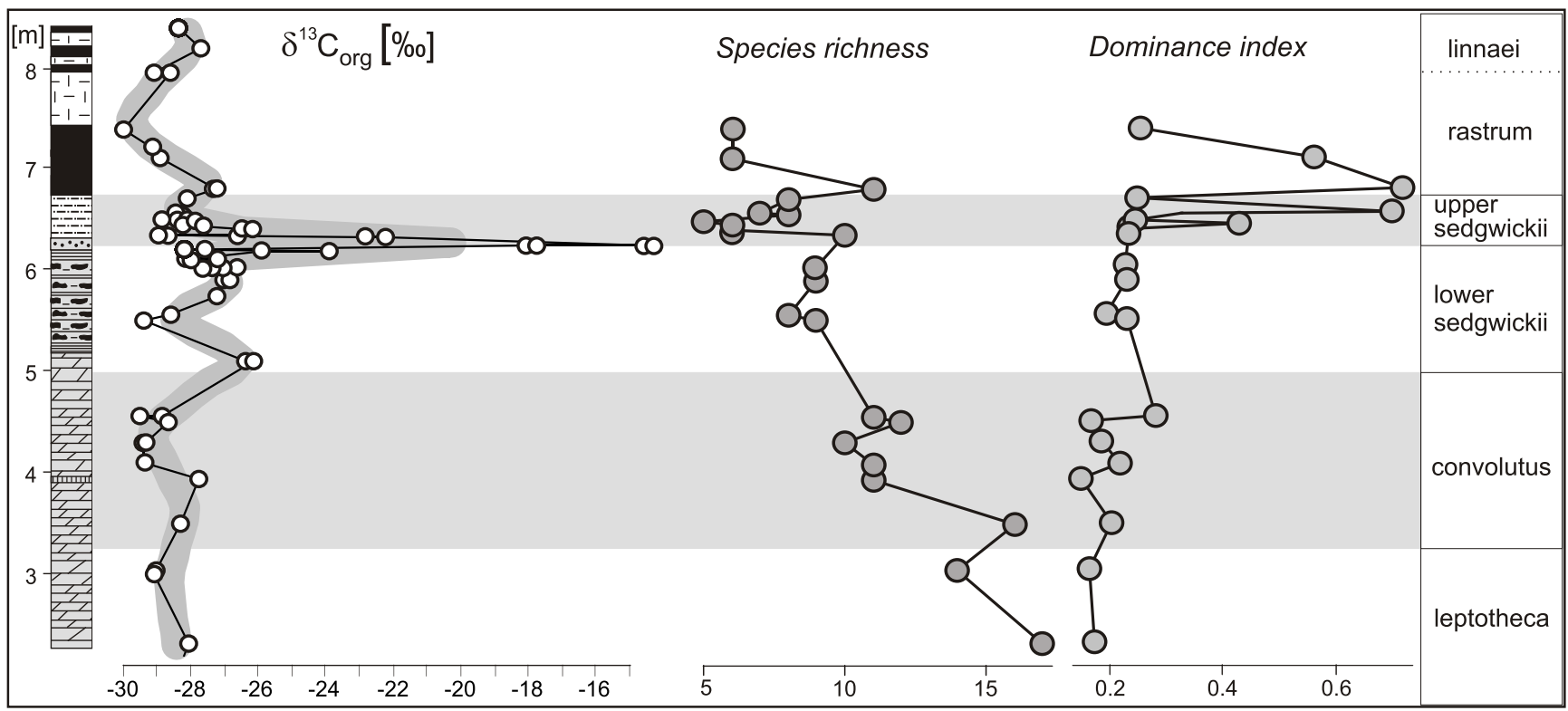

Fig. 4. Diagram showing $\delta^{13} \mathrm{C}$ record as well as species richness and dominance index calculated for individual samples from the Radotín tunnel section 
and Frýda, 2012: fig. 7a, b). On the other hand, no statistically significant trend in species richness was found for data from the upper sedgwickii and rastrum biozones. These results are consistent with the general trend in the number of graptolite species recorded from leptotheca to rastrum biozones at all available sections of the Barrandian area (see Štorch and Frýda, 2012: fig. 7d).

The analysis of evenness of graptolite communities revealed a statistically significant trend in increasing dominance within graptolite assemblages across the studied interval (Fig. 4). A more detailed view, however, shows that the dominance index (see Hammer and Harper, 2008) has quite different range for data from the leptotheca to lower sedgwickii biozones on the one hand and from data from the upper sedgwickii and rastrum biozones on the other (Fig. 4). In the first stratigraphical interval the dominance varies only slightly but it increased dramatically (three times) in three samples of the upper sedgwickii and lowermost rastrum biozones (Fig. 4).

Štorch and Frýda (2012) showed that a quantitative study of graptolite faunal dynamics has provided evidence for the complex and step-wise nature of the Late Aeronian graptolite crisis, which extended through the whole sedgwickii Biozone and well into the rastrum Biozone. They also noted that the rapid increase in the extinction rate of graptolite species started near the end of the convolutus Biozone and initially was partly balanced by an increased rate of graptolite speciation and/or immigration. The most distinctive decrease of the graptolite species diversity occurs in the middle of the sedgwickii Biozone, coincident with the Late Aeronian carbon isotope anomaly, which is associated with major sea-level drawdown.

Our new data suggest that the long-term and step-wise Late Aeronian graptolite crisis, which started near the end of the leptotheca Biozone, was most likely not strongly influenced by changes in oxygen level. There is no correlation between the species richness of graptolite communities and the level of sea water oxygenation inferred from geochemical proxies (Fig. 4). We document the intervals with similar environmental conditions have quite different graptolite species richness (see Fig. 4; compare a diversity of anoxic to dysoxic convolutus and upper sedgwickii biozones, or that of dysoxic to oxic lower sedgwickii, rastrum and linnaei biozones). On the other hand, the upper sedgwickii and rastrum biozones have similar (but both highly variable) levels of graptolite species richness regardless differences in oxygen level.

Collapse of the global carbon cycle during the Late Aeronian anomaly only emphasized the long-term and step-wise na- ture of the graptolite crisis but it considerably decreased evenness of the latest Aeronian graptolite communities. Only locally there seem to be a link between oxygenation and short-term, abrupt changes in graptolite diversity and dominance.

\section{CONCLUSIONS}

The main goal of this study was to test the hypothesis that distinct changes in graptolite faunal dynamics during the Aeronian, associated with the Late Aeronian graptolite mass extinction, are linked with changes in deep sea water oxygenation. Our data show that anoxic to dysoxic conditions prevailed during the interval corresponding to the convolutus Biozone. From the beginning of the sedgwickii Biozone interval oxygen level in deep sea water was considerably high, creating dysoxic to oxic conditions shortly before the time of the Late Aeronian carbon isotope positive anomaly. A rapid shift to a more dysoxic/anoxic environment occurred just after time of this anomaly and these conditions remained steady until the end of the sedgwickii Biozone interval. The oxygen level again increased during the time of the rastrum and linnaei biozones.

Comparison of graptolite diversity with these high-frequency changes in oxygenation of deep sea water revealed that the long-term and step-wise Late Aeronian graptolite crisis was most likely not significantly influenced by changes in oxygen level except at the time of the $\mathrm{C}$-isotope excursion. The collapse of global carbon cycle during the Late Aeronian probably only temporarily increased extinction rate of the long-term graptolite crisis and considerably decreased evenness of the uppermost Aeronian graptolite communities. The long-term Aeronian graptolite mass extinction was probably mainly driven by other biotic and/or abiotic causes.

Acknowledgements. This paper is a contribution to IGCP 591 and IGCP 596. The research was supported by a grant from the Czech Geological Survey (338800) and two grants from the Grant Agency of the Czech Republic (GAČR 13-15390 S and GAČR 15-13310 S). We are very grateful to M.J. Melchin for helpful comments on the manuscript and the English correction. The manuscript has benefited from stimulating reviews by S. Oszczepalski, Z. Sawłowicz and one anonymous reviewer. Efficient editorial handling by T. Peryt and E. Dabrowska-Jędrusik is greatly appreciated.

\section{REFERENCES}

Algeo, T.J., Maynard, J.B., 2004. Trace element behaviour and redox facies in core shales of the Upper Pennsylvanian Kansas-type cyclothems. Chemical Geology, 206: 289-318.

Bau, M., 1996. Controls on the fractionation of isovalent trace elements in magmatic and aqueous systems: evidence from $\mathrm{Y} / \mathrm{Ho}$, $\mathrm{Zr} / \mathrm{Hf}$, and lanthanide tetrad effect. Contributions to Mineralogy and Petrology, 123: 323-333.

Bond, D.P.G., Zato, M., Wignall, P.B., Marynowski, L., 2013. Evidence for shallow water "Upper Kellwasser" anoxia in the Frasnian-Famennian reefs of Alberta, Canada. Lethaia, 46: 355-368.

Bouček, B., 1953. Biostratigraphy, development and correlation of the Želkovice and Motol Beds of the Silurian of Bohemia. Sborník Ústředního Ústavu Geologického, Oddíl Paleontologický, 20: 421-484.
Calvert, S.E., Pedersen, T.F., 1993. Geochemistry of recent oxic and anoxic marine sediments: implications for the geological record. Marine Geology, 113: 67-88.

Cocks, L.R.M., Torsvik, T.H., 2013. New global palaeogeographical reconstructions for the Early Palaeozoic and their generation. Geological Society of London Memoirs, 38: 5-24.

Derry, L.A., Jacobsen, S.B., 1990. The chemical evolution of Precambrian seawater: evidence from REEs in banded iron formations. Geochimica et Cosmochimica Acta, 49: 1955-1963.

Emerson, S.R., Huested, S.S., 1991. Ocean anoxia and the concentrations of molybdenum and vanadium in seawater. Marine Geology, 34: 177-196.

Fedo, C.M., Eriksson, K.A., Krogstad, E.J., 1996. Geochemistry of shales from the Archean $(\sim 3.0 \mathrm{Ga})$ Buhwa Greenstone Belt, 
Zimbabwe: implications for provenance and source-area weathering. Geochimica et Cosmochimica Acta, 60: 1751-1763.

Frýda, J., Frýdová, B., 2014. First evidence for the Homerian (late Wenlock, Silurian) positive carbon isotope excursion from peri-Gondwana: new data from the Barrandian (Perunica). Bulletin of Geosciences, 89: 617-634.

Frýda, J., Frýdová, B., 2016. The Homerian (late Wenlock, Silurian) carbon isotope excursion from Perunica: does dolomite control the magnitude of the carbon isotope excursion? Canadian Journal of Earth Sciences, 53: 695-701.

Frýda, J., Štorch, P., 2014. Carbon isotope chemostratigraphy of the Llandovery in northern peri-Gondwana: new data from the Barrandian area, Czech Republic. Estonian Journal of Earth Sciences, 63: 220-226.

Frýda, J., Lehnert, O., Joachimski, M.M., 2014. First record of the early Sheinwoodian carbon isotope excursion (ESCIE) from the Barrandian area of northwestern peri-Gondwana. Estonian Journal of Earth Sciences, 64: 42-46.

Guo, Q., Shields, G.A., Liu, C., Strauss, H., Zhu, M., Pi, D. Goldberg, T., 2007. Trace element chemostratigraphy of two Ediacaran-Cambrian successions in South China: implications for organosedimentary metal enrichment and silicification in the early Cambrian. Palaeogeography, Palaeoclimatology, Palaeoecology, 254: 194-216.

Hammarlund, E.U., Dahl, T.W., Harper, D.A.T., Bond, D.P.G., Nielsen, A.T., Bjerrum, C.J., Schovsbo, N.H., Schönlaub, H.P. Zalasiewicz, J.A., Canfield, D.E., 2012. A sulfidic driver for the end-Ordovician mass extinction. Earth and Planetary Science Letters, 331-332: 128-139.

Hammer, Ř., Harper, D., 2008. Paleontological Data Analysis. Willey-Blackwell, Oxford.

Harper, D.A.T., Hammarlund, E.U., Rasmussen, C.M.Ř., 2014 End Ordovician extinctions: a coincidence of causes. Gondwana Research, 25: 1294-1307.

Hatch, J.R., Leventhal, J.S., 1992. Relationship between inferred redox potential of the depositional environment and geochemistry of the Upper Pennsylvanian (Missourian) stark shale member of the Dennis Lime-stone, Wabaunsee County, Kansas, USA. Chemical Geology, 99: 65-82.

Jones, B., Manning, D.A.C., 1994. Comparison of geochemical indices used for the interpretation of palaeoredox conditions in ancient mudstones. Chemical Geology, 111: 111-129.

Kimura, H., Watanabe, Y., 2001. Ocean anoxia at the Precambrian-Cambrian boundary. Geology, 29: 995-998.

Křiž, J., 1975. Revision of the Lower Silurian stratigraphy in Centra Bohemia. Věstník Ústředního Ústavu Geologického, 50: 275-282.

Kř́žż, J., 1992. Silurian field excursions: Prague Basin (Barrandian), Bohemia. National Museum Wales, Geological Series, 13:1-111.

Křižz, J., 1998. Silurian. In: Paleozoic of the Barrandian (Cambrian to Devonian) (eds. I. Chlupáč, V. Havlíček, J. Křiž, Kukal and P. Štorch): 79-101. Český Geologický Ústav, Praha.

Lee, S.G., Kim, Y., Chae, B.G., Koh, D.C., Kim, K.H., 2004. The geochemical implication of a variable Eu anomaly in a fractured gneiss core: application for understanding Am behavior in the geological environment. Applied Geochemistry, 19: 1711-1725.

Lepka, F., Podracký, P., Knotek, M., 1984. Possibilities of the use of geochemical criteria for stratigraphic division of silty-clayey sediments of Barrandian (in Czech). Acta Montana, 67: 59-74.

MacRae, N.D., Nesbitt, H.W., Kronberg, B.I., 1992. Development of a positive Eu anomaly during diagenesis. Earth and Planetary Science Letters, 109: 585-591.

Marešová, Z., 1973. Geological setting and possibilities of uranium distribution in the area of Barrandian lower Palaeozoic (in Czech). Open File Report, Archive of the Czechoslovak Uranium Industry, Příbram.

März, Ch., Beckmann, B., Franke, Ch., Vogt, Ch., Wagner, T., Kasten, S., 2009. Geochemical environment of the Coniacian-Santonian western tropical Atlantic at Demerara Rise. Palaeogeography, Palaeoclimatology, Palaeoecology, 273: 286-301.

Melchin, M.J., Mitchell, C.E., Holmden, C., Štorch, P., 2013. Environmental changes in the Late Ordovician-early Silurian: review and new insights from black shales and nitrogen isotopes. GSA Bulletin, 125: 1635-1670.
Morford, J.L., Emerson, S., 1999. The geochemistry of redox sensitive trace metals in sediments. Geochimica et Cosmochimica Acta, 63: 1735-1750

Myers, K.J., Wignall, P.B., 1987. Understanding Jurassic organic-rich mud-rocks - new concepts using gamma ray spectrometry and palaeoecology: examples from the Kimmeridge clay of Dorset and the Jet rock of Yorkshire. In: Marine Clastic Sedimentology (eds. J.K. Leggett and G.G. Zuffa): 175-192. Graham and Trotman, London.

Pašava, J., 2000. Normal versus metal-rich black shales in the Barrandian Neoproterozoic of the Teplá-Barrandian Unit: a summary with new data. Věstník Českého Geologického Ústavu, 75 : 229-239.

Pašava, J., Hladiková, J., Dobeš, P., 1996. Origin of Proterozoic metal-rich black shales from the Bohemian Massif, Czech Republic. Economic Geology, 91: 63-79.

Porębska, E., Sawłowicz, Z., 1997. Palaeoceanographic linkage of geochemical and graptolite events across the Silurian-Devonian boundary in Bardzkie Mountains (Southwest Poland). Palaeogeography Palaeoclimatology Palaeoecology, 132: 343-354.

Rasmussen, B., Buick, R., Taylor, W.R., 1998. Removal of oceanic REE by authigenic precipitation of phosphatic minerals. Earth and Planetary Science Letters, 164: 135-149.

Rimmer, S.M., 2004. Geochemical paleoredox indicators in Devonian-Mississippian black shales, central Appalachian Basin (U.S.A.). Chemical Geology, 206: 373-391.

Sugitani, K., Yamashita, F., Nagaoka, T., Minami, M., Yamamoto, K., 2006. Geochemistry of heavily altered Archean volcanic and volcaniclastic rocks of the Warrawoona Group, at Mt. Goldsworthy in the Pilbara Craton, Western Australia: implications for alteration and origin. Geochemical Journal, 40: 523-535.

Štorch, P., 1994. Graptolite biostratigraphy of the Lower Silurian (Llandovery and Wenlock) of Bohemia. Geological Journal, 29: 137-165.

Štorch, P., 2006. Facies development, depositional settings and sequence stratigraphy across the Ordovician-Silurian boundary: a new perspective from Barrandian area of the Czech Republic. Geological Journal, 41: 163-192.

Štorch, P., Frýda, J., 2012. The late Aeronian graptolite sedgwickii Event, associated positive carbon isotope excursion and facies changes in the Prague Synform (Barrandian area, Bohemia). Geological Magazine, 149: 1089-1106.

Štorch, P., Pašava, J., 1989. Stratigraphy, chemistry and origin of the Lower Silurian black graptolitic shale of the Prague Basin, Barrandian, Bohemia. Věstník Českého Geologického Ústavu, 64: 143-162.

Taylor, S.R., McLennan, S.M., 1985. The Continental Crustal: its Composition and Evolution. Blackwell, Oxford.

Tribovillard, N., Algeo, T.J., Lyons, T., Riboulleau, A., 2006. Trace metals as paleoredox and paleoproductivity proxies: an update. Chemical Geology, 232: 12-32.

Vandenbroucke, T.R.A., Emsbo, P., Munnecke, A., Nuns, N., Duponchel, L., Lepot, K., Quijada, M., Paris, F., Servais, T., Kießling, W., 2015. Metal-induced malformations in Early Palaeozoic plankton are harbingers of mass extinction. Nature Communications, 6: 7966.

Wignall, P.B., 1994. Black Shales. Oxford University Press, New York.

Wignall, P.B., Twitchett, R.J., 1996. Oceanic anoxia and the end Permian mass extinction. Science, 272: 1155-1158.

Wright, J., Schrader, H., Holser, W.T., 1987. Paleoredox variations in ancient oceans recorded by rare earth elements in fossil apatite. Geochimica et Cosmochimica Acta, 51: 631-644.

Yan, D.T., Chen, D.Z., Wang, Q.Ch., Wang, J.G., 2009. Geochemical changes across the Ordovician-Silurian transition on the Yangtze Platform, South China. Science in China, Series D-Earth Sciences, 52: 38-54.

Yarincik, K.M., Murray, R.W., Lyons, T.W., Peterson, L.C., Haug, G.H., 2000. Oxygenation history of bottom waters in the Cariaco Basin, Venezuela, over the past 578,000 years: results from redox-sensitive metals (Mo, V, Mn, and Fe). Paleoceanography, 15: 593-604. 